\title{
Pendidikan Multikultural di Pondok Pesantren
}

\author{
Muhadditsir Rifa'i ${ }^{1}$, Ery Khaeriyah ${ }^{2}$ \\ ${ }^{1}$ UIN Syeikh Nurjati Cirebon, Indonesia \\ ${ }^{2}$ UIN Syeikh Nurjati Cirebon, Indonesia \\ ${ }^{1}$ muhaddits@syekhnurjati.ac.id
}

\begin{abstract}
Abstrak:
Pendidikan multikulturalisme ini, sudah banyak dikaji dengan perspektif keilmuan berbeda. Keberagaman asal penduduk, santri dan siswa sekolah di Pondok Buntet Pesantren, menurut peneliti penting untuk mengetahui konsep pendidikan multikultural di lingkungan Pondok Buntet Pesantren, Cirebon. Karena itu, peneliti menderivasikan kajiannya dalam pertanyaan penelitian sebagai berikut: Konsep pendidikan multikultural apa yang diupayakan di lingkungan Pondok Buntet Pesantren?Apa dampak dari konsep pendidikan multikultural yang diupayakan di lingkungan Pondok Buntet Pesantren? Sejauh mana peran tokoh dan pimpinan pesantren terhadap konsep pendidikan multikultural yang diupayakan di lingkungan Pondok Buntet Pesantren? Penelitian ini dikategorikan sebagai penelitian kualitatif induktif, dengan pendekatan metode studi kasus. Teknik analisis datanya adalah konsep analisis deskriptifeksploratif dengan melibatkan tiga komponen analisis, yaitu reduksi data (data reduction), penyajian data (data dislay), dan penarikan kesimpulan (verification).
\end{abstract}

Kata Kunci: Multikulutalisme, Pendidikan, Pesantren

\begin{abstract}
:
Abstract. This multiculturalism education, has been widely studied with different scientific perspectives. The diversity of the origin of the population, students and school students in Pondok Buntet Pesantren, according to researchers, is important to know the concept of multicultural education in the Pondok Buntet Pesantren environment, Cirebon. Because of that, the researcher derivates his study in the following research questions: What concept of multicultural education is being pursued in the Pondok Buntet Islamic Boarding School environment? To what extent are the roles of pesantren leaders and leaders in the concept of multicultural education being pursued in the Pondok Buntet Pesantren environment? This research is categorized as inductive qualitative research, with a case study method approach. The data analysis technique is the concept of descriptive-exploratory analysis involving three
\end{abstract}


components of analysis, namely data reduction, data display (data dislay), and conclusion drawing (verification).

Keywords: Multiculturalism, Education, Pesantren

\section{Pendahuluan}

Pendidikan multikultural, secara praktik sejatinya telah lama dilakukan, terintegrasi, dan berkembang dengan sendirinya di lingkungan pesantren bahkan di lingkungan-lingkungan lain dalam sendi-sendi kehidupan masyarakat di Indonesia pada umumnya. Begitu pula yang terjadi dan telah berlaku di Pondok Buntet Pesantren, sebagai lembaga pendidikan yang sejak dahulu telah banyak menerima santri dari berbagai pelosok daerah dengan ragam etnis, suku, budaya dan bahkan berasal dari agama dan Negara yang berbeda-beda.

Pondok Buntet Pesantren sendiri merupakan salah satu pondok pesantren tertua di Jawa Barat berdiri sejak akhir abad ke-17 kurang lebih pada tahun 1770 M. Menurut catatan sejarah, ulama yang mendirikan pesantren ini adalah seorang mufti besar kesultanan Cirebon bernama Kiai Haji Muqoyyim bin Abdul Hadi,yang dikenal dengan sebutan Mbah Muqoyyim. ${ }^{1}$

Pondok Buntet Pesantren memiliki keunikan tersendiri, di mana antara masyarakat dan santri berada dalam satu lingkungan yang tidak terpisahkan. Sehingga santri dan masyarakat dapat berinteraksi secara langsung dalam setiap gerak kehidupan. Keunikan lainnya berupa masyarakat yang sangat heterogen, baik dari asal usul keluarga masyarakat maupun budaya yang berkembang dari asal usul keturunanya masing-masing, di mana masyarakat Pondok Buntet Pesantren sebagian besar adalah merupakan pendatang, baik dari suku jawa, sunda, maupun suku-suku lainnya.

Seiring perkembangan zaman, Pondok Buntet Pesantren yang semula merupakan pondok pesantren tradisional, kini berevolusi menjadi pondok pesantren semi modern, di mana salah satu cirinya telah berdirinya lembaga-lembaga pendidikan formal dari tingkat taman kanakkanak sampai lembaga pendidikan tinggi.

Pendidikan agama menjadi pokok dan ciri khas pendidikan yang diajarkan turun temurun dari generasi pertama sampai sekarang di lingkungan Pondok Buntet Pesantren, baik untuk santri, siswa sekolah maupun warga masyarakat melalui sumber utamanya yaitu Al-Qur'an dan Hadis. Untuk memahami dan menggali kandungan Al-Qur'an, para Kiai, ustaz dan guru di lingkungan Pondok Buntet Pesantren menggunakan kitab-kitab tafsir. Adapun kitab-kitab tafsir

\footnotetext{
1 A. Zaini Hasan, Perlawanan dari Tanah Pengasingan; Kiai Abbas, Pesantren Buntet dan Bela Negara. (Yogyakarta: LkiS, 2014): h.30
} 
yang digunakan adalah kitab tafsir Jalalaiyn dan tafsir munir. Sementara kitab-kitab Hadis, dikaji dan yang dipelajari adalah kitab Arba'in Nawawi, Bulughul Maram, Shahih Bukhari, Shahih Muslim dan kitab-kitab kitab-kitab Hadis lainnya.

Bagi kalangan santri dan warga masyarakat Pondok Buntet Pesantren sendiri, tidaklah menjadi sesuatu yang asing dengan Pendidikan agama khususnya dengan kajian-kajian kitab kuning. Namun bagi sebagian anak didik yang bersekolah di SMK-NU (Sekolah Menengah Kejuruan- Nahdlatul Ulama), Pendidikan agama bisa jadi merupakan hal baru yang mereka pelajari atau merupakan pendidikan lanjutan dari sekolah tingkat di bawahnya. Sebab, sebagian dari mereka merupakan lulusan non-pesantren yang berasal dari sekolah-sekolah umum serta tidak menetap sebagai santri di pondok-pondok pesantren yang ada di lingkungan Pondok Buntet Pesantren.

Dari keragaman santri dan masyarakat yang ada di Pondok Buntet Pesantren tersebut, selama ini tidak pernah muncul perilaku ataupun sikap-sikap yang menjurus rasis, diskriminatif maupun anarkis. Meskipun secara suku, ras maupun budaya mereka berbeda-beda. Melihat fakta tersebut, dapat ditarik kesimpulan sementara bahwasanya konsep pendidikan multikultural yang diajarkan di lingkungan Pondok Buntet Pesantren, baik di sekolah-sekolah, santri maupun warga masyarakat telah sesui dan berjalan dengan baik.

Melihat fakta tersebut di atas, konsep pendidikan multikultural yang diajarkan di lingkungan Pondok Buntet Pesantren telah sesuai dengan apa yang dikehendaki dalam penyelenggaraan pendidikan nasional, sebagaimana tertuang dalam Pasal 4 UU N0. 20 Tahun 2003 Sistem Pendidikan Nasional. Dalam pasal itu dijelaskan, bahwa pendidikan diselenggarakan secara demokratis, tidak diskriminatif dengan menjunjung tinggi HAM, nilai keagamaan, nilai kultural dan kemajemukan bangsa.

Peran seorang tokoh atau pimpinan pesantren, guru dan tokoh masyarakat lainnya di lingkungan Pondok Buntet Pesantren dalam menentukan konsep pendidikan multikultular menjadi menarik sekaligus unik untuk diteliti. Namun, di sisi lain lembaga pendidikan Islam di Indonesia dikritik karena telah mempraktikkan proses pendidikan yang eksklusif, dogmatis dan kurang menyentuh moralitas. ${ }^{2}$

Praktek kekerasan yang mengatasnamakan suku, agama, ras dan antar golongan ditengarai karena munculnya gerakan-gerakan yang bersifat radikal. Praktek kekerasan ini jika dibiarkan, dikhawatirkan akan menjerumuskan terjadinya perpecahan bangsa. Kasus konflik

\footnotetext{
${ }^{2}$ M. Amin Abdulah, Pengajaran Kalam dan Teologi di Era Kemajemukan (Sebuah Tinjauan materi dan Metode Pendidikan Agama), dalam Thashwirul Afkar, no 11 tahun 2001
} 
yang terjadi beberapa tahun terakhir dibeberapa daerah di Jakarta, Jawa Barat, Jawa Timur dan di tempat-tempat lainnya sampai aksi teror bom seperti yang terjadi di Bali, Kuningan Jakarta dan tempat lainnya sangat memprihatinkan.

Di tingkat global, munculnya gerakan Islamic State of Irak and Syiria (ISIS), diyakini karena pemahaman keliru mengenai beberapa teks sumber ajaran agama Islam. Hal tersebut tidak saja memberikan ancaman terhadap proses keberagamaan, akan tetapi dapat pula meningkatkan intensitas konflik dalam keragaman, konflik antar agama, juga berdampak pada ketegangan dalam intra agama. Pemahaman-pemahaman radikal dari kelompok ISIS semakin melebarkan sayapnya hingga sampai ke Indonesia.

Dampak kehadiran mereka dapat membahayakan proses kerukunan berbangsa dan bernegara dan pada gilirannya akan mengancam keutuhan Negara Kesatuan Republik Indonesia. Pergerakanannya semakin massif melalui gerakan massa, lembaga-lembaga masyarakat sampai lembaga-lembaga yang berbalut keagamaan. Hal ini jelas menggambarkan betapa pemahaman agama sebagian masyarakat masih sangat rentan untuk disusupi dengan paham-paham radikal, yang bisa saja disampaikan dalam ruang publik, semisal sekolah, pesantren atau bahkan di perguruan tinggi.

Untuk itu, konsep pendidikan multikultural sangatlah dibutuhkan serta hadirnya diharapkan mampu menjadi inovasi dan reformasi yang integral dan komprehensif dalam muatan-muatan pendidikan; merekonstruksi pengetahuan tentang pemahaman teks-teks keagamaan yang bebas prasangka, rasis, bias, dan stereotipe. Pendidikan multikultural sejatinya memberi pengakuan akan pluralitas, yang dapat dijadikan sarana belajar untuk perjumpaan lintas batas, dan mentransformasi indoktrinasi menuju pendidikan yang dialogis dan humanis.

Berangkat dari latar belakang yang terurai di atas, peneliti menganggap pentingnya untuk mengetahui dan mengkaji konsep pendidikan multikultural yang dipraktikan di lingkungan Pondok pesantren khususnya di Pondok Buntet Pesantren, Cirebon, Jawa Barat. Oleh karena itu, peneliti menderivasikan pengkajian pendidikan multikultural di lingkungan Pondok Buntet Pesantren dalam pertanyaan penelitian sebagai berikut: Konsep pendidikan multikultural apa yang diupayakan di lingkungan Pondok Buntet Pesantren? Apa dampak dari konsep pendidikan multikultural yang diupayakan di lingkungan Pondok Buntet Pesantren? Sejauh mana peran tokoh dan pimpinan pesantren terhadap konsep pendidikan multikultural yang diupayakan di lingkungan Pondok Buntet Pesantren?

\section{Pengertian Pendidikan Multikultular}


Secara etimologis, istilah pendidikan multikultural berasal dari dua kata pendidikan dan multikultural. Pendidikan merupakan proses pengembangan sikap dan tata laku seseorang atau sekelompok orang dalam usaha mendewasakan manusia melalui pengajaran, pelatihan, proses, perbuatan dan cara-cara yang mendidik. Disisi lain, pendidikan adalah Transfer of knowledge atau memindah ilmu pengetahuan. Sedangkan multikultural secara etimologis multi berarti banyak, beragam dan aneka sedangkan kultural berasal dari kata culture ${ }^{3}$ yang mempunyai makna budaya, tradisi, kesopanan atau pemeliharaan. Rangkaian kata pendidikan dan multikultural memberikan arti secara terminologis adalah proses pengembangan seluruh potensi manusia yang menghargai pluralitas dan heterogenitasnya sebagai konsekwensi keragaman budaya, etnis, suku dan aliran (agama). Zakiyuddin Baidhawi mendefnisikan pendidikan multikultural adalah suatu cara untuk mengajarkan keragaman (teaching diversity). ${ }^{4}$

\section{H.A.R.Tilaar Tilaar menjelaskan pendidikan multikultural merupakan proses} pengembangan sikap dan tata laku seseorang atau sekelompok orang dalam usaha mendewasakan manusia melalui upaya pengajaran, pelatihan, proses, perbuatan, dan cara-cara mendidik yang menghargai pluralitas dan heterogenitas secara humanistik. Pendidikan adalah sebuah konsep, ide atau falsafah sebagai suatu rangkaian kepercayaan (set of believe) dan penjelasan yang mengakui dan menilai pentingnya keragaman budaya dan etnis di dalam membentuk gaya hidup, pengalaman sosial, identitas pribadi, kesempatan- kesempatan pendidikan dari individu, kelompok maupun negara. Tilaar mengemukakan gagasan mengenai pendidikan multikultural adalah sebagai tawaran konsep bagi dunia pendidikan Indonesia ke depan, khususnya pendidikan yang bercirikan Islam yang ada di Indonesia dalam hal ini adalah madrasah. ${ }^{5}$

\section{Konsep Dasar Pendidikan Multikultular}

3 Alo Liliweri M.S. (2003: 7-9), dalam bukunya "Makna Budaya dalam Komunikasi Antarbudaya, mengutip lebih dari lima makna kebudayaan". Pertama, menurut Iris Varner dan Linda Beamer, dalam Inter-cultural Communication in the Global Workplace, mengartikan kebudayaan sebagai pandangan yang koheren tentang sesuatu yang dipelajari, yang dibagi, atau yang dipertukarkan oleh sekelompok orang. Pandangan itu berisi apa yang mendasari kehidupan, apa yang menjadi derajat kepentingan, tentang sikap mereka yang tepat terhadap sesuatu, gambaran suatu prilaku yang harus diterima oleh sesama atau yang berkaitan dengan orang lain. Kedua, kebudayaan, dalam arti yang luas, adalah perilaku yang telah tertanam, ia merupakan totalitas dari sesuatu yang dipelajari manusia, akumulasi dari pengalaman yang dialihkan secara sosial disosialisasikan), tidak sekedar sebuah catatan ringkas, tetapi dalam bentuk prilaku melalui pembelajaran sosial (Social Learning). Ketiga, kebudayaan adalah komunikasi simbolis, simbolisme itu adalah ketrampilan kelompok, pengetahuan, sikap, nilai, dan motif. Makna dari simbol-simbol itu dipelajari dan disebarluaskan dalam masyarakat melalui institusi. Untuk memperdalam tentang kebudayaan dan ruang lingkupnya lebih lanjut baca (T.O. Ihromi,1996), (Van Peursen, 1985), (Achdiat M. Miharja, 1977), (Suwardi Endraswara, 2003)

${ }^{4}$ Baidhawi, Zakiyuddin, Pendidikan Agama Berwawasan Multikultural(Jakarta: Erlangga, 2005), h. 8

${ }^{5}$ H.A.R. Tilaar, Multikulturalisme, tantangan tantangan Global Masa Depan dalam Transformasi Pendidikan Nasional. (Jakarta: Grasindo, 2004): h. 79 
Mengenai obyek pendidikan multikultural, Tilaar mengungkapkan bahwa dalam program pendidikan multikultural, obyek tidak lagi diarahkan semata-mata kepada kelompok rasial, agama dan kultural domain atau mainstream. Obyek seperti ini pernah menjadi tekanan pada pendidikan interkultural yang menekankan peningkatan pemahaman dan toleransi individuindividu yang berasal dari kelompok minoritas terhadap budaya mainstream yang dominan, yang pada akhirnya menyebabkan orang-orang dari kelompok minoritas terintegrasi ke dalam masyarakat mainstream. Pendidikan multikultural sebenarnya merupakan sikap "peduli" dan mau mengerti (difference), atau "politics of recognition" politik pengakuan terhadap orang-orang dari kelompok minoritas. ${ }^{6}$

Menurut Tilaar, pendidikan multikultural bermula dari gagasan dan kesadaran tentang "interkulturalisme" seusai perang dunia ke-dua. Kemunculan gagasan dan kesadaran “interkulturalisme" ini, selain terkait dengan perkembangan politik internasional menyangkut hak asasi manusia (HAM), kemerdekaan dari kolonialisme, dan diskriminasi rasial dan lainlain, juga karena meningkatnya pluralitas di negara-negara Barat sendiri seiring meningkatnya migrasi dari negara-negara baru merdeka ke Amerika dan Eropa.

Munculnya pergerakan sipil seperti itu akhirnya berpengaruh pada dunia pendidikan, tuntutannya adalah mengubah kurikulum dan system pendidikan yang saat itu lebih kental mengandung unsur diskriminatif. Munculnya gagasan tentang pendidikan multikultural itu berkembang pada tahun 1970-an dengan menguatnya wacana pendidikan yang menekankan pada aspek-aspek yang berkorelasi dengan keragaman budaya dan etnik (cultural diversity). ${ }^{7}$

Atas dasar keragaman tersebut, maka sudah logis jika kemudian konsep dan system pendidikan yang seharusnya dikembangkan adalah pendidikan yang bernuansa keragaman juga, yakni pendidikan multikultural. Sedangkan pendidikan Agama berbasis multikultural sendiri secara dasar bisa dirujuk dari Lawrence J. Saha. Menurutnya, pendidikan multikultural dalam hal ini termasuk pendidikan agama dapat dipahami sebagai proses atau strategi pendidikan yang melibatkan lebih dari satu budaya dan agama, yang ditunjukan melalui kebangsaan, bahasa, etnik, atau kriteria rasial. Pendidikan agama berwawasan multikultural dapat dilaksanakan baik dalam pendidikan formal maupun informal.

Sementara target dan tujuan pendidikan agama multikultural sendiri diarahkan untuk mewujudkan kesadaran toleransi, pemahaman, dan pengetahuan yang mempertimbangkan

\footnotetext{
6 Azumardi Azra, "Identitas dan Krisis Budaya, Membangun Multikulturalisme Indonesia", dalam http:/budpar.go.id/agenda/precongress/ makalah/abstrak/58 \% 20 azra.htm, diakses 03 Desember 2019

7 J.A. Banks. An introduction to Multicultural Education, (Boston-London: Allyn and Bacon Press, 2004): h.4-5
} 
perbedaan kultur (budaya), dan juga perbedaan dan persamaan antar budaya dan kaitannya dengan pandangan dunia, konsep, nilai, keyakinan agama dan sikap dalam masyarakat. James Banks mengemukakan, sebagaimana yang dikutip Yani Kusmasrni bahwa pendidikan mulktikultural memiliki lima dimensi yang saling berkaitan satu sama lain, yaitu:

1. Content integration; mengintegrasikan berbagai budaya dan kelompok untuk mengilustrasikan konsep dasar, generalisasi dan teori dalam pelajaran (disiplin ilmu)

2. The Knowledge Consturuction Process; membawa peserta didik untuk memahami implikasi budaya ke dalam sebuah pelajaran

3. An Equity Paedagogy; menyesuaikan metode pembelajaran dengan cara belajar peserta didik. Hal ini dilakukan dalam rangka memfasilitasi prestasi akademik siswa yang beragam, mulai dari ras, budaya maupun sosial

4. Prejudice Reduction; mengidentifikasi karakteristik ras dan menentukan metode pembelajaran peserta didik

5. Melatih peserta didik untuk berpartisipasi dalam kegiatan olah raga dan berinteraksi dengan seluruh staff serta peserta didik yang berbeda etnik dan ras dalam upaya menciptakan budaya akademik

\section{Multikultularisme Perspektif Al-Quran}

Pendidikan Islam hadir untuk mengembangkan semua aspek dalam kehidupan manusia yang meliputi unsur-unsur spritual, intelektual, imajinasi, keilmiahan; baik individu maupun kelompok, dan memberi dorongan bagi dinamika perkembangan aspek-aspek di atas menuju kebaikan dan pencapaian kesempurnaan hidup baik dalam hubungannya dengan Tuhan, sesama manusia, maupun dengan alam.

Dengan demikian, tujuan pendidikan Islam ditetapkan oleh Allah untuk memenuhi keperluan hidup manusia itu sendiri, baik keperluan primer (al-maqasidu al-khamsah), sekunder (hajiyat), dan tertier (tahsinat). ${ }^{8}$ Oleh karena itu, apabila seorang muslim mengikuti ketentuan-ketentuan yang ditetapkan Allah, maka ia akan selamat baik di dunia maupun di akhirat.

Tujuan pendidikan Islam bukan sebatas mengisi pikiran seorang murid dengan ilmu pengetahuan dan materi pelajaran akan tetapi membersihkan jiwanya yang harus diisi dengan akhlak dan nilai-nilai yang baik dan dikondisikan supaya biasa menjalani hidup dengan baik. ${ }^{9}$

8 Juhaya S. Praja, Epistemologi Hukum Islam (Jakarta: IAIN, 1988): h. 196

${ }^{9}$ Athiyyah al-Abrasyi, At-Tarbiyyah al-Islamiyyah wa Falsafatuha (Beirut: Dar al-Fikr. 1969): h. 22 
Dari tujuan pendidikan Islam tersebut, dapat disimpulkan bahwa seorang murid diharapkan dapat menjadi manusia yang berakhlak mulia dan dapat mengenal masyarakat lain serta menghargai keragaman budayanya. Hal tersebut senada dengan prinsip yang ada dalam pendidikan multikultural.

Senada dengan pernyataan terebut di atas Allah Swt. berfirman dalam Al-Quran surat AlHujurat ayat 13:

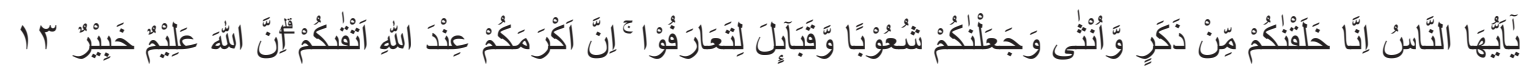
Artinya:"Wahai manusia! Sungguh, Kami telah menciptakan kamu dari seorang laki-laki dan seorang perempuan, kemudian Kami jadikan kamu berbangsa-bangsa dan bersuku-suku agar kamu saling mengenal. Sesungguhnya yang paling mulia di antara kamu di sisi Allah ialah orang yang paling bertakwa. Sungguh, Allah Maha Mengetahui, Maha teliti."

Ayat di atas menjelaskan bahwa Allah Swt. telah menciptakan makhluk-Nya, laki-laki dan perempuan, dan menciptakan manusia berbangsa-bangsa, untuk menjalin hubungan yang baik. Kata ta'arafu pada ayat ini maksudnya bukan hanya berinteraksi tetapi berinteraksi positif. Jadi dijadikannya makhluk dengan berbangsa-bangsa dan bersuku-suku adalah dengan harapan bahwa satu dengan yang lainnya dapat berinteraksi secara baik dan positif. Lalu dilanjutkan dengan ... inna akramakum ,ndallahi atqaakum.. maksudnya, bahwa interaksi positif itu sangat diharapkan menjadi prasyarat kedamaian di bumi ini. Namun, yang dinilai terbaik di sisi Allah adalah mereka itu yang betul-betul dekat kepada Allah.

Allah Swt. sengaja menciptakan manusia dalam keadaan yang berbeda. Dalam Al-Quran Surah al-Maidah ayat 48 Allah berfirman:

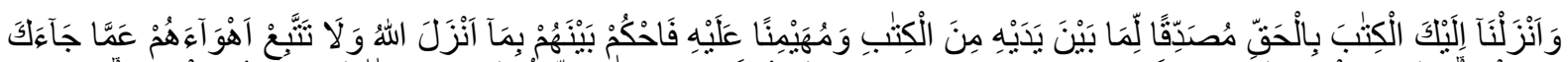

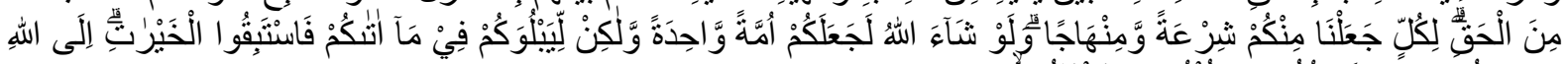

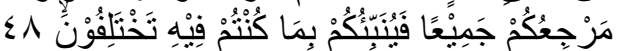

Artinya:'Dan Kami telah menurunkan Kitab (Al-Qur'an) kepadamu (Muhammad) dengan membawa kebenaran, yang membenarkan kitab-kitab yang diturunkan sebelumnya dan menjaganya, maka putuskanlah perkara mereka menurut apa yang diturunkan Allah dan janganlah engkau mengikuti keinginan mereka dengan meninggalkan kebenaran yang telah datang kepadamu. Untuk setiap umat di antara kamu, Kami berikan aturan dan jalan yang terang. Kalau Allah menghendaki, niscaya kamu dijadikan-Nya satu umat (saja), tetapi Allah hendak menguji kamu terhadap karunia yang telah diberikan-Nya kepadamu, maka berlomba-lombalah berbuat kebajikan. Hanya kepada Allah kamu semua kembali, lalu diberitahukan-Nya kepadamu terhadap apa yang dahulu kamu perselisihkan."

Dalam tafsir Al-Maraghi dijelaskan bahwa Allah Swt. menurunkan Taurat, lalu Injil kepada Bani Israil, dan Dia terangkan petunjuk maupun cahaya yang Dia pesankan dalam kedu kitab itu, serta Dia jelaskan pula kewajibanyang harus mereka tunaikan untuk menegakkan keduanya, serta ancaman-Nya terhadap mereka berupahukuman apabila tidak menggunakan kedua kitab tersebut dalam memutuskan perkara, maka sesudah itu, Allah terangkan disini, bahwa Dia telah menurunkan Al-Quran atas nabi-Nya yang terakhir, Muhammad Saw., dan 
betapa kedudukan kitab Al-Quran ini diantara kitab-kitab lain sebelumnya. Bahwa hikmahnya adalah memerlukan adanya berbagai macam syari'at dan jalan untuk memberi petunjuk kepada umat manusia. ${ }^{10}$

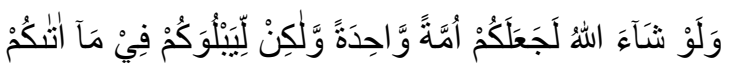

Kalau Allah menghendaki untuk menjadikan kamu suatu umat saja dengan satu syari'at dan satu jalan yang kamu tempuh dan amalkan, uakni dengan menciptakan kalian berwatak dan berakhlak sama, dan penghidupanmu pun satu taraf, sehingga kamu bisa diatur dengan satu syari'at saja dalam berbagai masa. Jadi, kamu sama dengan jenis-jenis makhluk lainnya yang wataknya tetap berada pada suatu tahap tertentu. Andaikan demikian, tentu Allah Swt. lakukan itu.

Namun, Allah tidak menghendaki itu. Bahkan, Dia berkehendak menjadikan kalian suatu jenis makhluk yang berakal, berpikir dan mempunyai watak dapat memahami dan siap menerima ilmu, berkembang melewati tahapan-tahapan hidup sedikit demi sedikit, tunduk pada undang-undang perkembangan. ${ }^{11}$ Yakni Allah mensyari'atkan berbagai macam syari'at untuk menguji hamba-hamba-Nya, dengan apa yang Allah syari'atkan kepada mereka, guna memberikan pahala kepada mereka dan siksaan kepada mereka, atas ketaatan atau kedurhakaan yang telah mereka lakukan, atau yang telah mereka rencanakan untuk melakukan semua itu. ${ }^{12}$

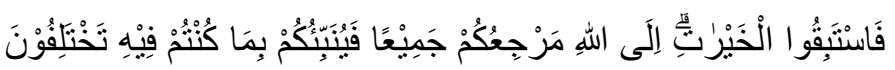

Kalau demikian halnya, seperti apa yang telah disebutkan diatas, maka cepat-epatlah kalian melakukan hal-hal yang menjadi kebaikan dam amal-amal saleh, mumpung masih ada kesempatan untuk itu, dan agar kamu menjadi umat yang lebih utama. ${ }^{13}$ Maksudnya, Allah menganjurkan mereka untuk cepat dan segera menuju kepada kebaikan. Yaitu, taat kepada Allah, dan mengikuti syari'at-syari'at yang Allah jadikan sebagai penasakh (yang mengnghapus) bagi syari'at-syari'at sebelumnya, serta membenarkan Kitab-Nya, yaitu AlQuran yang merupakan Kitab yang terakhir kali diturunkan-Nya

Al-Quran surah Ar-Ruum ayat 22:

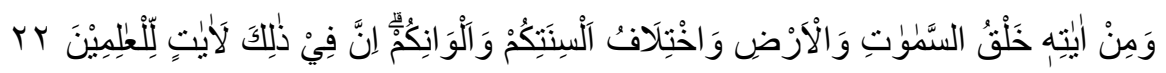

"Dan di antara tanda-tanda (kebesaran)-Nya ialah penciptaan langit dan bumi, perbedaan bahasamu dan warna kulitmu. Sungguh, pada yang demikian itu benar-benar terdapat tanda-tanda bagi orang-orang yang mengetahui."

\footnotetext{
${ }^{10}$ Ahmad Mustafa Al-Maraghi, Tafsir Al-Maraghi, (Semarang: Karya Toha, 1993): vol. 6, h. 237-238

${ }^{11}$ Ahmad Mustafa Al-Maraghi, Tafsir Al-Maraghi Juz VI (Semarang: Karya Toha, 1993): h.239

${ }^{12}$ Ibnu Katsir, Tafsir Al-Quran Al-Adzim (Kairo: Maktabah Awlad Al-Syaikh, 2000): vol. 6, h, 103

${ }^{13}$ Ahmad Mustafa Al-Maraghi, Tafsir Al-Maraghi Juz VI (Semarang: Karya Toha, 1993): h.240
} 
Ada beberapa versi penafsiran mengenai ayat di atas oleh beberapa ahli tafsir. Di antaranya adalah: Menurut Ibnu Katsir ${ }^{14}$, di antara tanda-tanda kekuasaan-Nya adalah penciptaan langit dan bumi. Dalam arti penciptaan langit dengan ketinggiannya, keluasan hamparan atapnya, kecemerlangan bintang-bintangnya yang tetap dan yang beredar. Serta penciptaan bumi dengan kerendahan dan ketebalannya serta beberapa kandungannya seperti bentuk gunung, oase, laut, padang pasir, hewan, dan pepohonan. Tanda-tanda kekuasaan Allah yang berikutnya adalah perbedaan bahasa-bahasa yang ada. Ada yang berbahasa Arab, Tartar, Romawi, Perancis, Barbar, Habsyi, Hindi, 'Ajam, Armenia, Kurdi, dan masih banyak lagi. ${ }^{15}$ Keseluruhan dari keragaman bahasa tersebut tidak ada yang mengajarkannya kecuali Allah.

Tanda-tanda selanjutnya adalah keragaman warna kulit manusia. Seluruh penduduk Bumi, sejak diciptakannya Adam sampai hari akhir, semuanya memiliki dua mata, dua alis, satu hidung, dua buah pelipis, satu mulut, dan dua pipi. Meskipun demikian, antara satu dengan yang lainnya tidak memiliki kesamaan. Bahkan dibedakan satu sama lain antara jalannya, sikapnya atau pembicaraannya. Baik nyata ataupun tersembunyi yang hanya dapat terlihat jika melalui perenungan.

Seandainya seluruh manusia memiliki kesamaan dalam ketampanan atau kejelekan, niscaya dibutuhkan orang yang membedakan setiap salah satu di antara mereka dengan yang lainnya. ${ }^{16}$ Hampir tidak ada satupun orang kecuali anda berbeda dengannya dan dia berbeda dengan lainnya. ${ }^{17}$

Menurut Imam Al-Qurthubi, hal ini jelas terjadi bukan karena air mani maupun perbuatan dari kedua orang tua. Pasti terdapat pelaku atas semua ini, dan dapat dipastikan bahwa pelakunya adalah Allah Swt. Hal ini merupakan dalil yang menunjukkan adanya Tuhan Yang Maha Mengatur dan Maha Menciptakan.

Sedangkan dalam Tafsir fi Zhilalil-Qur'an jilid 9, Sayyid Quthb menerangkan bahwa tanda-tanda kekuasaan Allah Swt. dalam penciptaan langit dan bumi kerap disebutkan di dalam Al-Quran, tetapi kita sering sekali melewatinya dengan cepat-cepat tanpa berhenti lama dihadapannya. ${ }^{18}$ Padahal hal tersebut sangat layak untuk direnungkan dan dipikirkan.

Menurut beliau, penciptaan langit dan bumi memiliki makna sebuah ciptaan yang besar, agung, dan amat cermat. Jumlah planet, meteor, bintang, matahari, awan, dan tata surya adalah jumlah yang tidak terhingga. Sehingga jika dibandingkan, bumi ini tak lebih dari sebuah atom

\footnotetext{
${ }^{14}$ Ibnu Katsir. Tafsir Ibnu Katsir (Jilid 7): h. 168

${ }^{15}$ Ibnu Katsir. Tafsir Ibnu Katsir (Jilid 7): h. 169

${ }^{16}$ Ibnu Katsir. Tafsir Ibnu Katsir (Jilid 7): h. 16

${ }^{17}$ Syaikh Imam Al-Qurthubi. Tafsir Al-Qurthubi (Jilid 14): h. 42

${ }^{18}$ Sayyid Quthb. Tafsir fi Zhilalil-Qur'an (Jilid 9): h. 139
} 
tak berbobot yang tidak memiliki pengaruh apapun terhadap semesta. Di samping keragaman dan jumlah planet yang tak terhingga ini terdapat hal mengagumkan yang lainnya. Yakni adanya garis orbit, perputaran, dan gerakan masing-masing planet yang menimbulkan keserasian dan keselarasan antara satu dengan yang lainnya.

Adapun penciptaan manusia dengan berbagai macam bahasa dan warna kulit, menurut Sayyid Quthb memiliki korelasi dengan penciptaan langit dan bumi yang mengagumkan ini. Adanya perbedaan hawa udara di permukaan bumi dan perbedaan lingkungan yang terjadi karena tabiat kedudukan bumi secara astronomis, mempunyai implikasi terhadap perbedaan bahasa dan warna kulit.

Dalam pembahasan mengenai tanda-tanda kekuasaan Allah Swt., sebagaimana yang telah disebutkan di atas. Sayyid Quthb juga mengkritik paradigma ilmuwan kontemporer. Menurut beliau, kebanyakan ilmuwan saat ini memang menyadari adanya perbedaanperbedaan warna dan bahasa. Mereka mempelajari fenomena ini secara obyektif saja dan melewatkan kehendak serta kekuasaan Allah Swt. dalam hal tersebut. Mereka tidak melakukan perenungan akan hal itu untuk kemudian dikembalikan kepada Sang Khaliq yang mengatur segala hal baik lahir ataupun batin.

Dari ketiga penafsiran yang telah disampaikan di atas, dapat kita ambil pengetahuan secara umum bahwasanya keteraturan, keselarasan, dan keserasian dalam penciptaan langit dan bumi merupakan tanda-tanda Keagungan Allah Swt. Munculnya ilmu pengetahuan merupakan pembuktian adanya Sang Pencipta dan bukan sebaliknya.

\section{Konsep Pendidikan Multikultural di Lingkungan Pondok Buntet Pesantren dalam Praktik}

Sebagaimana umumnya aktifitas pesantren, pendidikan dalam rangka untuk membentuk insan berkarakter multikultural dapat terlihat dari aktifitas kajian yang sengaja diprogramkan. Adanya Forum Musyawarah Kubra dan Bahtsul Masail, misalnya, adalah bentuk pembelajaran yang akan mengasah santri peka terhadap perbedaan dan belajar bagaimana menyikapinya. Musyawarah Kubra adalah forum yang diikuti semua santri Pondok Buntet Pesantren untuk membahas berbagai fenomena sosial yang muncul yang selanjutnya mencoba dilihat dalam perspektif Islam.

Forum ini diadakan dalam satu bulan sekali, yang terkadang mendatangkan nara sumber dari luar pesantren. Dituturkan, Kang Ugi panggilan akrab K.H. Ahmad Syauqi sebagai Pengurus Lembaga Bahtsul Masail NU (LBM-NU) pernah mengundang KH. Muthohhar, M.Pd.I, sebagai nara sumber dalam forum ini. Forum Bahtsul Masail adalah ajang santri untuk 76 | IQ (Ilmu Al-qur'an): Jurnal Pendidikan Islam | Volume 2 No. 012019 
berpendapat dalam menyikapi permasalahan sosial dan mencari kesimpulan hukumnya dalam Islam. Tentu dalam Forum Bahtsul Masail santri secara tidak langsung belajar berbeda dan harus menghargai perbedaan itu.

Kemajemukan masyarakat, santri dan siswa yang menuntut ilmu di Pondok Buntet Pesantren cukup menarik untuk dikaji dan dipaparkan. Pada kenyataannya, santri ternyata bisa berinteraksi dengan masyarakat yang berbeda, baik suku, ras, etnis bahkan berbeda dalam akidah. Sehingga, dalam acara-acara ritual mereka dapat lebur sekedar meramaikan. Misalnya, pada peringatan Haul Almarhumin dan Warga Pondok Buntet Pesantren, selain tampil bentuk kesenian Islami seperti hadroh dan kosidah juga ditampilkan Barong Sai dari masyarakat Tionghoa. Hal ini ditegaskan sendiri oleh pandangan pengasuh- pengasuhya, antara lain $\mathrm{KH}$. Hasanuddin Kriyani, KH. Ahmad Mursyidin, KH. Anas Arsyad dan lainnya, bahwa bagian dari pola pikir humanisme, kalangan pesantren tidak menghalangi pergaulan dengan kelompok-kelompok lain walaupun berbeda agama.

Selain itu, dengan keberadaan santri yang datang dari berbagai daerah, dituturkan misalnya, dari Medan, Jakarta, Jambi, palembang, Lampung, NTT, Indaramayu, Brebes, dan lainnya adalah corak tersendiri dalam perbedaan. Mereka akan saling belajar memahami budaya yang berbeda dan bagaimana cara hidup bersama dalam perbedaan.

Praktik kehidupan multikultural juga terlihat dari interaksi sosial kemasyarakatan antar etnis dan agama di Pondok Buntet Pesantren. Seperti diceritakan, misalnya Koh Husein (Liem Hua) dikenal dekat dengan warga dan para Kyai-kyai. Ia sering berkunjung ke pesantren dan memberikan makanan kepada santri. Kyai pun mengajarinya berbagai do'a penyembuhan dari Al-Quran dan Hadits, tanpa memaksanya untuk memeluk agama Islam. Ilmu penyembuhan itu kini diturunkan ke anak cucunya. Dengan begitu Perbedaan etnis dan agama bukan kendala dalam menjalin hubungan sosial. Sampai pada suatu saat, tanpa ada paksaan sama sekali, ia masuk Islam.

Tidak berbeda dengan Tionghoa, etnis Bali (Ade) pun mampu menyesuaikan diri. Ia hidup dan menetap di Buntet Pesantren, sudah hampir 30 tahun lamanya, menyatakan bahwa; "Dalam pergaulan sehari-hari orang-orang Bali tidak menghadapi kendala. Apalagi kultur atau "unggah-ungguh" orang Bali dan orang Cirebon memang memiliki banyak kesamaan.

Adapun praktik pendidikan multikultural yang terjadi di sekolah-sekolah yang bernaung dalam Yayasan Lembaga Pendidikan Islam (YLPI) Buntet Pesantren terjadi dalam beberapa kegiatan, di antaranya melalui kegiatan seni yang menampilkan kesenian dari berbagai kesenian daerah asal dari para siswa. Kesenian-kesenian yang ditampilkan biasanya adalah, 
seni tari saman dari Aceh, tari topeng dari Cirebon, genjringan dari Palembang, Barong Sai dari etnis Tionghoa, dan lain sebagainya.

\section{Potensi Konflik}

Sekalipun hingga kini (2018) tidak pernah terjadi konflik serius dalam komunitas plural Arjawinangun, namun potensi meletusnya konflik pasti ada. Ibarat bom waktu, konflik di komunitas plural kapanpun siap meledak. Namun itupun sangat tergantung dari pola relasi sosial dan komunikasi antar etnis dan komunitas agama yang ada. Memang riak-riak kecil sempat muncul dan menimbulkan pergesekan, tetapi tidak sampai meletus hebat. Hal itu tidak dipungkiri oleh para tokoh dan Kyai, menurutnya konflik kecil beberapa kali pernah terjadi. Perselisihan bermula dari kasus kriminal biasa. Situasi makin panas, ketika persoalan ditarik ke wilayah SARA (suku, ras, dan agama). Untungnya gesekangesekan itu tidak pernah berkembang lebih jauh. Para tokoh dari berbagai elemen masyarakat baik pesantren, gereja, maupun Tionghoa segera mengambil langkah-langkah dialog untuk meredam konflik. Sampai sekarang Buntet Pesantren aman dan damai. Dalam beberapa tahun terakhir, hampir tidak pernah muncul kasus-kasus pergesekan yang murni dipicu oleh isu etnis atau agama. Hal itu dikuatkan oleh fakta pada Mei 1998 ketika beberapa wilayah lain bergejolak, Buntet Pesantren tidak terkena imbas. Kerusuhan Mei tidak berpengaruh apapun. Kondisi kondusif diakui beberapa tokoh karena para tokoh lintas etnis dan agama selalu berkomunikasi dan melakukan dialog.

\section{Kesimpulan}

Kajian ini menyimpulkan tiga hal: Kesimpulan Pertama, Buntet Pesantren kini dikenal sebagai Pondok Pesantren yang sangat kental dengan ciri khas mengibarkan bendera multikulturalisme yang didukung oleh dua hal: pertama, kondisi realitas keragaman etnis asal penduduk, santri dan siswanya berikut keragaman budayanya serta agama sejak lama ada di Buntet Pesantren. Kedua, latar belakang pendidikan pendiri dan pengasuh Buntet Pesantren yang beragam, bahkan beberapa merupakan alumnus dari luar negeri, sehingga pengalamanpengalaman itu yang kemudian mewarnai pemikiran dan cara hidup dalam kebersamaan di tengah keragaman. Kesimpulan kedua, Dalam rangka untuk membentuk insan berkarakter multikultural, yakni insan yang mengenal, menerima, menghargai keberagaman, Buntet Pesantren menempuhnya melalui dua konsep, yaitu pertama melalui konsep kajian yang dapat membuka wawasan santri untuk dapat mengenal perbedaan, dan kedua melalui konsep keteladanan dalam bentuk interaksi sosial. Kesimpulan ketiga, praktik pendidikan multikultural yang dilakukan di lingkungan Pondok Buntet Pesantren baik melalui konsep 
kajian maupun konsep keteladanan, keduanya dapat dikatakan membuahkan hasil yang memuaskan, ditandai dengan realitas kehidupan sosial yang harmonis, tidak atau belum pernah terjadi konflik serius antar etnis atau budaya apalagi konflik agama.

\section{Daftar Pustaka}

Abdulah, M. Amin, Pengajaran Kalam dan Teologi di Era Kemajemukan (Sebuah Tinjauan materi dan Metode Pendidikan Agama), dalam Thashwirul Afkar, no 11 tahun 2001

Al-Abrasyi, Athiyyah, At-Tarbiyyah al-Islamiyyah wa Falsafatuha, Beirut: Dar al-Fikr. 1969

Al-Maraghi, Ahmad Mustafa, Tafsir Al-Maraghi, Semarang: Karya Toha, vol. 6, 1993

Al-Qurthubi, Syaikh Imam. Tafsir Al-Qurthubi (Jilid 14)

Azra, Azumardi, "Identitas dan Krisis Budaya, Membangun Multikulturalisme Indonesia", dalam http:/budpar.go.id/agenda/precongress/ makalah/abstrak $158 \% 20$ azra.htm, diakses 03 Desember 2019

Baidhawi, Zakiyuddin, Pendidikan Agama Berwawasan Multikultural, Jakarta: Erlangga, 2005

Banks James A., (ed), Handbook of Research on Multikultural Education, 2001 An introduction to Multicultural Education, Boston-London: Allyn and Bacon Press, 2004

David, Jari dan Jary, Julia, Multikulturalism, Dictionary of Sosiologi. New York: Harper, 1991

Dewey, Jhon, Democracy and Education, dalam H.A.R Tilaar, Multikulturalisme, tantangan tantangan Global Masa Depan dalam Transformasi Pendidikan Nasional. Jakarta: Grasindo, 2004

Dodi, Limas, Relevansi Pemikiran Multikultural Abdurrahman Wahid, Jurnal Empirisma,Vol 20 N0 2, juli 2011

Hasan, A. Zaini, Perlawanan dari Tanah Pengasingan; Kiai Abbas, Pesantren Buntet dan Bela Negara. Yogyakarta: LkiS, 2014

Katsir, Ibnu, Tafsir Al-Quran Al-Adzim, Kairo: Maktabah Awlad Al-Syaikh, vol. 6, 2000 M.S., Alo Liliweri, dalam bukunya “Makna Budaya dalam Komunikasi Antarbudaya.”, 2003 Marimba, Ahmad D., Pengantar Filsafat Pendidikan Islam, Bandung: al-Ma'arif, 1962 Moleong, Lexy, Metodologi Penelitian kualitatif. Bandung : Remaja Roasdakarya, 2005 Praja, Juhaya S., Epistemologi Hukum Islam, Jakarta: IAIN, 1988 
Muhadditsir Rifa'i dan Ery Khaeriyah

Quthb, Sayyid, Tafsir fi Zhilalil-Qur'an (Jilid 9)

Tilaar, H.A.R., Multikulturalisme, tantangan tantangan Global Masa Depan dalam Transformasi Pendidikan Nasional. Jakarta: Grasindo, 2004

Tobroni, Imam Suprayogo dan, Metodologi Penelitian Sosial Agama. Bandung: Rosyda Karya, 2001 